\title{
Mediasi dalam Penyelesaian Sengketa Medik Dokter dengan Pasien (Analisis Putusan PN No. 38/Pdt.G/2016/PN.Bna dan Putusan Mahkah Agung No. 1550 K/Pdt/2016)
}

\author{
Nurul Ummah, Fifik Wiryani, Mokhammad Najih \\ Magister Ilmu Hukum, Direktorat Program Pascasarjana, Universitas Muhammadiyah \\ Malang, Jl. Raya Tlogomas No. 246 Malang \\ E-mail: fwiryani2016@gmail.com
}

\begin{abstract}
Mediation is a form of negotiation in an effort to resolve disputes both from parties who feel aggrieved by the related parties. Mediation is also able to produce a peace agreement from both parties so that it can provide benefits for both. Dispute resolution efforts can use several means of mediation, including through litigation and non-litigation, both of which have their own advantages and disadvantages. In the case in Banda Aceh, the legal route was prioritized compared to mediation because of the patient's dissatisfaction, as well as the case of cassation decisions that did not receive the compensation offered by the defendant so that the court route was taken. The mediation used did not have a positive impact on both parties so that the mediation was considered a failure. Mediating is expected to provide good and fair benefits to all disputing parties so as to produce a sense of satisfaction and justice without any shortcomings of both. This mediation is also regulated in 1999 Law number 30 concerning arbiterage and options for resolving disputes that are outside the court and according to the 2008 regulation number 1 regarding mediation in court which was later refined back to the Supreme Court regulation of the Republic of Indonesia No.1 of 2016. This research is a descriptive type of juridical normative research, with an approach to the law and secondary data obtained from various types of literature studies and document studies, then the data is analyzed qualitatively. With the result that the hope that the legislation has been perfected is that the dispute resolution process outside the court can be more optimal, and also that the community feels much better benefits and benefits from the existence of mediation.

Keyword: Mediation, Medical Disputes, District Court Decisions, Cassation Decisions;
\end{abstract}




\begin{abstract}
Abstrak
Mediasi merupakan bentuk negosiasi dalam upaya penyelesaian sengketa baik dari pihak yang merasa dirugikan dengan pihak terkait. Mediasi juga mampu melahirkan kesepakatan perdamaian dari kedua belah pihak sehingga bisa memberikan manfaat untuk keduanya. Upaya-upaya penyelesaian sengketa bisa menggunakan beberapa cara mediasi antara lain melalui jalur litigasi dan non litigasi, kedua hal ini memiliki keuntungan dan kerugian tersendiri. Dalam kasus di banda aceh lebih mengedepankan jalur hukum di bandingkan mediasi karena rasa tidak puasan pasien, begitu juga dengan kasus putusan kasasi yang tidak menerima kompensasi yang ditawarkan oleh pihak tergugat sehingga jalur pengadilan yang ditempuh. mediasi yang digunakan tidak memberikan dampak positif bagi kedua belah pihak sehingga mediasi dianggap gagal. Dengan bermediasi diharapkan memberikan manfaat yang baik dan adil bagi seluruh pihak yang bersengketa sehingga menghasilkan rasa kepuasaan dan keadilan tanpa ada kekurangan dari keduanya. Mediasi ini juga diatur pada UU tahun 1999 nomer 30 tentang arbiterase dan opsi dalam menyelesaikan sengketa yang berada di luar pengadilan dan menurut perma tahun 2008 nomer 1 terkait mediasi dalam pengadilan yang kemudian di sempurnakan kembali pada peraturan Mahkamah Agung Republik Indonesia no.1 tahun 2016. Penelitian ini bersifat deskriptif dengan jenis penelitian yuridis normatif, dengan pendekatan pada Undang-undang dan data sekunder yang diperoleh dari berbagai mcam studi pustaka dan studi dokumen, kemudian data di analisa secara kualitatif. Dengan hasil bahwa harapan telah di sempurnakannya peraturan perundang-undangan adalah proses penyelesaian sengketa yang berada diluar pengadilan bisa lebih optimal, dan juga masyarakat merasakan manfaat dan keuntungan yang jauh lebih baik terhadap adanya mediasi.

Kata Kunci: Mediasi, sengketa medik, putusan PN, putusan kasasi;
\end{abstract}

\title{
A. PENDAHULUAN
}

Manusia adalah mahluk individu dan sosial, yang juga dituntut mampu melakukan hubungan baik dengan sesama yang selaras srasi dan seimbang. Akan tetapi akan jauh berbeda jika dihubungankan dengan hukum yang mana dalam kenyataannya seringkali tidak sejalan dan tidak sama bahkan seringkali tidak lancar. Terkadang muncul suatu kondisi yang mana salah satu pihak tidak mampu memenuhi seluruh kewajibannya terhadap pihak lain, mengakibatkan pihak tersebut merasa dirugikan, yang pada akhirnya menimbulkan perselisihan/sengketa. Dalam rangka menajamin keberlangsungan hubungan dari kedua belah pihak maka permasalahan ini harus segera diselesaikan, agar supaya tidak berkepanjangan.

Semenjak dahulu kala sesungguhnya masyarakat telah mengenal yang namanya musyawarah dan mufakat, yang kemudian dalam penyelesian ini melibatkan beberapa tokoh 
masyarakat ataupun tokoh-tokoh adat sehingga menghasilkan keputusan yang bisa di terima oleh seluruh pihak yang bermasalah. ${ }^{1}$

Sampai saat ini banyaknya permasalahan di masyarakat baik dari hal yang terkecil hingga hal yang terbesar membuat permasalahan hukum di indonesia semakin banyak dan menghawatirkan. Tak jarang masyakar sekarang lebih suka melakukan melakukan hukum sendiri atau hukum yang berlaku di masyarakat dibandingkan dengan menyelesaikan seluruh perkara di meja hijau, hal ini di karenakan kurangnya rasa percaya dan ketidak puasan masyarakat terhadap seluruh purusan yang di tetapkan oleh pengadilan. Kebanyakan masyarakat menganggap hukum saat ini bisa di beli tanpa melihat salah dan benar, untung dan ruginya dari pihak-pihak yang bersengketa.

Pada umumnya yang menjadi pemicu dari sengketa adalah sebuah kesalah pahaman dari kedua belah pihak terkait informasi yang kurang akurat, sehingga menimbulkan multi tafsir, kecurigaan, kesalah fahaman, ketidak puasan, tersinggung, kecurangan, ketidak jujuran, semena-mena, ketidak adilan, sehingga timbul sesuatu hal yang tidak diduga-duga. ${ }^{2}$

Salah satu contohnya adalah sengketa medik yang sering kali menjadi momok di masyarakat, sengketa medik ini seringkali menjadi permasalahan tersendiri bagi warga yang tidak banyak mengetahui prosedur dan tatacara penangana pasien ataupun pelayanan pasien di rumah sakit, begitu juga sebaliknya masih banyak sekali tenaga kesehatan yang sering mengenyampingkan pelayanan yang kurang memuaskan dan juga infrom concent kepada pasien yang seharunya pasien dapatkan saat melakukan transaksi kesehatan. ${ }^{3}$

Dalam keseharian masyarakat sudah sering kali mendengar kata-kata sengketa, terutam pada kasus medis kata sengketa masih terasa asing dan jarang sekali orang mengetahui istilah ini, akan tetapi akhir-akhir ini beberapa orang menyebutnya dengan sengketa di bagian medis. Istilah yang semacam ini juga masih sedikit orang yang mengetahunya hanya terbatas pada kalangan ahli kesehatan saja, sedangkan masyarakat lebih mengetahuinya sebagai malpraktik. Sengketa sendiri lebih diartikan sebagai perselisihan.

Menurut beberapa ahli mengatakan ada dua hal yang terjadi dalam kehidupan masyarakat yaitu konflik (conflict) atau sengketa (dispute), ${ }^{4}$ sesungguhnya kedua hal ini adalah sama namun memiliki arti yang berbeda dari keduanya, konflik sendiri memiliki arti yang sangat luas dan jika terjadi peselisihan akan lama dan jarang sampai mencuat kepermukaan, namun jika hal ini sampai mencuat maka bisa dikatakan sebagai sebuah sengketa. Kebanyakan orang-orang tertentu masih belum tahu dan tidak menyadari jika sedang mengalami konflik namun bagi

\footnotetext{
${ }^{1}$ Septi Wulan Sari, "Mediasi Dalam Peraturan Mahkamah Agung No1 Tahun 2016," Jurnal Ahkam 5, no. 1 (2017): 1-16.

${ }^{2}$ Dedi Afandi, "Mediasi: Alternatif Penyelesaian Sengketa Medis," Majalah Kedokteran Indonesia 59, no. 5 (2009): 189-92.

3 Ahmad Zulfikar, "Upaya Penyelesaian Sengketa/Konflik Pertanahan,” Jurnal Lex Specialis 21, no.1 (2015): 74-85, https://core.ac.uk/download/pdf/76936466.pdf

${ }^{4}$ Marsella, "Perspektif Penanganan Sengketa Pertanahan di Badan pertanahan Nasional," Penegakan Hukum 2, no. 2 (2015): 101-107, http://www.ojs.uma.ac.id/index.php/gakkum/article/download/2066/1752
} 
orang yang yang berkonflik maka akan mengetahu dengan gamblang, hal ini akan menjadi mengemuka jikalau yang berkoflik melakukan sesuatu hal yang membuat sesorang tersebut mengetahu jika ada permasalahan. ${ }^{5}$

Umumnya sengketa medik dilakukan oleh pasien kepada pihak RS atau dokter atau ahli kesehatan terkait yang dianggap telah melakukan kerugian bagi pasien atau melakukan kesalahan oleh pihak pihak terkait, kemudian membuat aduan ke pihak polisi atau juga gugatan ke pengadilan. ${ }^{6}$ Kemudian disinilah yang bisa dikatakan sebagai sengketa antara pasien dengan dokter atau rumah sakit. Sesungguhnya istilah malpraktik tidaklah pantas atau bisa dikatakan kurang tepat, karena sesungguhnya ini merupakan suatu praduga bersalah oleh doker atau pihak rumah sakit, praduga-praduga ini bisa dipakai oleh pihak tertentu untuk memperoleh kepentingan sesaat yang kemudian bisa mengakibatkan kerugian dan rusaknya tatanan dalam sistem pelayanan kesehatan. ${ }^{7}$

Perbuatan-perbuatan malpraktik medis dikemudian hari akan memberikan dampak sangat luas secara yuridis, baik dalam hukum perdata, pidana, dan hukum administrasi, contohnya dalam hukum perdata adalah perbuatan wanprestasi. ${ }^{8}$ Hukum pidana contohnya adalah melakukan tindakan penipuan kepada pasien yang mana dokter telah memberikan keterangan palsu atau tidak sesuai fakta, pada waktu menjalankan profesinya melakukan tindakan pelanggaran kesusilaan, secara sengaja telah melakukan tindakan penelantaran pasien. Hukum administrasi misalnya, dokter yang telah atau sedang melakukan praktik kedokteran tidak memiliki STR yang sebelumnya di terbitkan oleh KKI, yang seharusnnya bagia dari bentuk kewajiban dokter seperti yang telah diperintahkan UU nomer 29 Tahun 2004 tentang Praktik Kedokteran, kemudian Pasal 29 ayat 1, yang kemudian bagi mereka yang sudah memiliki STR maka diwajibkan baginya memiliki surat izin praktik/SIP. Dalam Pasal 36 UU No. 29 Tahun 2004 tentang Praktik Kedokteran, yang sudah dikeluarkan kepala dinas kesehatan di mana tempat melakukan praktik kedokteran. ${ }^{9}$

Seperti di dalam putusan pengadilan terhitung sampai januari 2019 ada sekitar 319 kasus yang sudah diputuskan di pengadilan, Contoh kasus pada tahun 2016 dengan putusan No.38PDT. G/BNA dengan kasus kelalaian dokter kandungan yang berakibatkan meninggalnya ibu dan anak korban. Pertanggung jawaban atas meninggalnya pasien dan anak pasien seperti dalam Pasal 1367/KUHPerdata, "seseorang tidak hanya memiliki tanggung jawab untuk

${ }^{5}$ Mohammad Irfan and Syamsul Hidayat, "Mediasi Sebagai Pilihan Penyelesaian Sengketa Medik Dalam Hukum Positif Indonesia,” Jurnal IUS 6, no. 3 (2018).

${ }^{6}$ Ari Purwadi, "Prinsip Praduga Selalu Bertanggung-Gugat dalam Sengketa Medik," Padjadjaran Jurnal Ilmiah Hukum 4, no.1 (2017): 104-121, http://jurnal.unpad.ac.id/pjih/article/view/11509

${ }^{7}$ Rini Anggraini, Suryono Yudha Patria, and Madarina Julia, "Ketepatan Waktu Pelayanan Skrining Hipotiroidism Kongenital Di Yogyakarta,” Sari Pediatri 18, no. 6 (2017): 436, https://doi.org/10.14238/sp18.6.2017.436-42.

${ }^{8}$ Gaby Pratty Ombeng, "WANPRESTASI TERHADAP ISI PERJANJIAN DIVESTASI ANTARA PEMERINTAH INDONESIA DAN PT. NEWMONT NUSA TENGGARA,” Lex Privatum 1, no. 5 (2015): 3739, https://ejournal.unsrat.ac.id/index.php/lexprivatum/article/view/3080/2624.

${ }^{9}$ Sari, "Mediasi Dalam Peraturan Mahkamah Agung No1 Tahun 2016." 
mengganti kerugian yang disebabkan olehnya, namun juga bertanggung jawab atas kerugiaan di di akibatkan oleh orang yang menjadi tanggungjawabnya". ${ }^{10}$ Dalam putusan pengadilan memutuskan mengabulkan dan menolak sebagian, dengan rincian membayar ganti rugi sebesar Rp. 200.000.000,- ditanggung renteng oleh para tergugat dengan rincian tergugat 1 sebanyak $70 \%$, tergugat $215 \%$, tergugat $315 \%$, dan total keseluruhan pembayaran ganti rugi, menolak gugatan penggugat selain dan selebihnya. Menolak gugataan pengggutan rekonvensi/ tergugat 3 konvensi, menghukum tergugat 1, 2, 3 konvensi/penggugatan rekonvensi secara tanggung renteng untuk membayar seluruh biaya perkara sebesar Rp. 4.709.000,-. ${ }^{11}$

Kasus ke dua yakni putusan Mahkamah Agung No. $1550 \mathrm{~K} / \mathrm{Pdt} / 2016^{12}$ dengan hasil kecacatan permanen kaki pasien karena kesalahan prosedur pemasangan screw di lutut pasien sehingga mengharuskan pasien untuk operasi kembali yang kedua dengan mengorbankan otot hamstring kaki kanan pasien. Putusan pengadilan negeri tersebut dikuatkan oleh putusan Pengadilan Tinggi Bandung No. 369/Pdt/2015/PT.Bdg, tertanggal 27 Oktober 2015. Mengadili menolak permohonan kasasi dari pemohon kasasi tersebut, menghukum kasasi/penggugat/pembanding untuk membayar biaya perkara dalam tingkat kasasi senilai Rp. 500.000,- dan ditetapkan pada tanggal 8/November $2016 .{ }^{13}$

Dalam perkembangan ilmu yang semakin moderen penyelesaian sengketa saat ini lebih dikenal dengan nama mediasi, upaya-upaya mediasi ini kemudian diharapkan menghasilkan perdamaian karena kedua belah pihak bisa mengemukakan seluruh pendapat dan usulan sesuai dengan kebutuhan masing-masing. Terkadang dalam bermediasi ada yang belum mencapai kata sepakat, meskipun demikian kedua belah pihak sebelumnya telah menyampaikan seluruh aspirasi dan harapan dalam dirinya, sehingga pihak lain mengetahui harapan dan keinginan pihak lain.

Di Indonesia saat ini mengenal dua hal dalam upaya penyelesaian sengketa yakni litigasi (pengadilan) ${ }^{14}$ dan non litigasi (luar pengadilan), selain itu ada beberapa cara lainnya dalam penyelesaian sengketa yakni arbiterase, konsiliasi atau mediasi. Dari bebrapa cara penyelesaian sengketa kebanyakan masyarakat sekarang lebih menggunakan metode mediasi di luar pengadilan, karena dianggap lebih effesien dan efektif dan juga singkat. Untuk mewadahi mediasi maka ada suatu lembaga yang membantu dalam proses bermediasi baik lembaga yang langsung di tunjuk oleh pengadilan yang dianggap pihak ketiga dan bersifat netral tidak

${ }^{10}$ Direktori Putusan et al., "Putusan Nomor 38/Pdt.G/2016/PN.Bna” (Banda Aceh: putusan mahkamah agung indonesia, 2016).

11 Moch. Nassir Nurul Ummah, Fifik Wiryani, "Perbuatan Melanggar Hukum Dalam Pelayanan Kesehatan (Analisis Putusan PN No.38/Pdt.G/2016/PN.Bna Dan Putusan Kasasi No.1550 k/Pdt/2016),” Magister Hukum Kesehatan UMM (Mhammadiyah Malang, 2018).

12 derektori putusan mahkamah agung republik Indonesia, "Putusan Nomor 1550 K/Pdt/2016" (Bandung: direktori putusan mahkamah agung indonesia, 2016).

${ }^{13}$ Nurul Ummah, Fifik Wiryani, "Perbuatan Melanggar Hukum Dalam Pelayanan Kesehatan (Analisis Putusan PN No.38/Pdt.G/2016/PN.Bna Dan Putusan Kasasi No.1550 k/Pdt/2016).”

${ }^{14}$ https://ejournal.uniska-kediri.ac.id/index.php/Mizan/article/download/1057/841 
memihak kepada siapapun, atau juga mediator yang di minta oleh pihak-pihak terkait untuk menyelesaikan sengketa mereka.

Adapun rumusan masalah pada penelitian ini adalah: pertama, bagaimana manfaatmanfaat mediasi dalam penyelesaian sengketa medik dokter dengan pasien (Analisis Putusan PN No.38/Pdt.G/2016/PN.BNA dan Putusan Kasasi No. 1550 K/Pdt/2016)? Kedua, bagaimana kerugian-kerugian yang didapat dari mediasi dalam penyelesaian sengketa medik dokter dengan pasien (Analisis Putusan PN No.38/Pdt.G/2016/PN.Bna dan Putusan Kasasi No.1550 $\mathrm{k} / \mathrm{pdt} / 2016)$.

Kontribusi penelitian ini adalah: pertama, memberikan pengetahuan lebih mendalam dan memberikan informasi terkait mediasi yang bisa memberi keuntungan, kemanfaatan dari proses mediasi yang di kehendaki oleh pihak terkait baik mediatornya dipilih oleh pihak-pihak yang bersengketa ataupun yang telah di tunjuk oleh pengadilan. Kedua, untuk mengetahui dampak kerugian yang diperoleh dari mediasi litigasi dan non litigasi dengan dasar hukum yang jelas.

\section{B. METODE PENELITIAN}

Penelitian ini bersifat deskriptif dengan memakai teknik penelitian hukum normatif, ${ }^{15}$ yang berumber pada data sekunder. Data sekunder sendiri, terdiri atas badan hukum primer (yang mengatur tenatng aturan perundang-undangan dan kejelasan tercatat lainnya) dan sekunder (berasal dari sebuah teori, berbagai macam pembelajaran, pendapat dari para ahli atau orang yang menguasai dibidangnya). ${ }^{16}$ Penulis lebih mengutamakan dalam penggunaan hukum normatif demi memperoleh suatu file yang sudah diyakini atau ditetapkan sebelumnya ${ }^{17}$.

Sumber yang diperoleh berasal dari berbagai macam literatur, peraturan perundangundangan, buku-buku, artikel, makal, jurnal, dan masih banyak lainnya. Data ini sebagai landasan dasar pengetahuan dan penelitian untuk mengakhiri suatu permasalahan, norma-norma baik secara menyeluruh dan juga yang seringkali ada .

Adapun bahan hukum primer yang digunakan dalam penelitian ini, meliputi:

1. Putusan Pengadilan Negeri No.38/Pdt.G/2016/PN.Bna ${ }^{18}$ dan Putusan Mahkamah Agung Nomor $1550 \mathrm{~K} / \mathrm{Pdt} / 2016^{19}$ pada tangkat kasasi.

2. UU Nomor 30 Tahun 1999 tentang arbiterase Alternatif Penyelesaian Sengketa.

3. Pasal 23 Peraturan Mahkamah Agung No.1/2008 terkait mediasi dalam pengadilan.

4. Penyempurnaan peraturan sebelumnya terait mediasi oleh peraturan Mahkamah Agung Republik Indonesia no. 1 tahun 2016. ${ }^{20}$

\footnotetext{
${ }^{15}$ Peter Mahmud Marzuki, Penelitian Hukum (Jakarta: Kencana, 2005).

${ }^{16}$ Sari, "Mediasi Dalam Peraturan Mahkamah Agung No1 Tahun 2016."

${ }^{17}$ Margerita Veani Prajati, "Penyelesaian Sengketa Medik Antara Pasien Dengan Dan/Atau Dokter Gigi Serta Rumah Sakit Demi Mewujudkan Hak Pasien," Universitas Atmajaya (Atmajaya Yogyakarta, 2014).

${ }^{18}$ Putusan et al., "Putusan Nomor 38/Pdt.G/2016/PN.Bna."

${ }^{19}$ Indonesia, "Putusan Nomor 1550 K/Pdt/2016."

${ }^{20}$ Sari, "Mediasi Dalam Peraturan Mahkamah Agung No1 Tahun 2016."
} 
Sedangkan bahan hukum sekunder yang digunakan dalam penelitian ini, didapatkan oleh penulis dengan cara melakukan studi pustaka, yaitu mendokumentasikan data yang diperoleh dari file-file yang menjadi persoalan medik, buku-buku, makalah ataupun artikel dan beberapa jurnal penelitian beserta acuanyang berkaitan dengan cara penulisan jurnal penelitian.

Sifat analisis yang digunakan untuk menganalisa adalah analisa kualitatif pada data sekunder, langkahnya berupa dokumen yang di ambil dari bahan hukum primer atau sekunder, setelah itu dilakukan penganalisaan agar supaya menjadi sama akan pendapat-pendapat untuk melindungi orang-orang yang menerima layanan kesehatan pada sengketa medik, kemudian menganalisa mediasi dilihat dari hukum positif di indonesia.

\section{HASIL DAN PEMBAHASAN}

\section{Mediasi litigasi dan non litigasi sebagai bentuk upaya dalam penyelesaian sengketa medik dokter dan pasien}

Kewajiban dalam putusan dan pertimbangan logika medis dan hukum didalam upaya penyelesaian sengketa adalah guna untuk bisa menentukan sengketa medik tersebut masuk dalam kategori-kategori malpraktik kedokteran atau tidak, dan juga harus melakukan kajian hukum kepada dokter dan atau rumah sakit bahwa segala perbuatannya tidaklah salah/buruk, begitu juga dengan seluruh hal buruk tidak selalu bisa dikaitkan dengan malpraktik kedokteran. Kemudian setelah itu baru bisa dilakukan sebuah telaah baru untuk mengambil keputusan dan kesimpulan masuk ke dalam hukum pidana atau perdata, pelanggaran etika kedokteran dan juga disiplin kedokteran. ${ }^{21}$

Kasus yang menjadi perselisihan antara pasien dengan dokter dan atau rumah sakit termasuk di dalamnya adalah orang yang sudah merasa dirugikan oleh mereka atas tindakannya, seperti pada pasal 66 UU/No.66/2004 terkait praktik kedokteran. Yakni persoalan yang sedang berlangsung lebih baik di selesaikan secara mediasi dikarenakan hal ini menguntungkan kedua belah pihak. Jikapun diharus untuk diselesaikan oleh sebuah badan independen guna untuk disiplin ilmu kedokteran, maka akan menyita waktu yang cukup lama dan juga keputusan yang sudah diambil belum tentu bisa memberi kepuasan kedua belah pihak yang terkait dengan putusan dari pihak pemutus, yang sudah dilakukan oleh anggota MKDKI. ${ }^{22}$

Mediasi merupakan bentuk/cara menyelesaikan sengketa melalui jalur perundingan dari kedua belah pihak demi mendapatkan kata sepakat dari pihak-pihak terkait yang di bantu/didampingi oleh seorang mediator (baik fasilitas mediator dari pengadilan atau dari luar pengadilan). ${ }^{23}$ Asal mula kata mediasi adalah dari bahasa inggris yang artinya menjadi

${ }^{21}$ Indar, Aminuddin syam, and Muh. Alwy Arifin, Etika Kesehatan Masyarakat (Yogyakarta: Pustaka Pelajar, 2018), https://www.docdroid.net/d7YQZw9/buku-etika-kesehatan-masyarakat-pdf\#page=15. Indonesia."

${ }^{22}$ Irfan and Hidayat, "Mediasi Sebagai Pilihan Penyelesaian Sengketa Medik Dalam Hukum Positif

${ }^{23}$ Sari, "Mediasi Dalam Peraturan Mahkamah Agung No1 Tahun 2016." 
penengah dalam proses penyelesaian sengketa. ${ }^{24}$ Proses-proses ini juga dikatakan sebagai bentuk negosiasi untuk menyelesaiakn persoalan beberapa pihak terkait dengan tidak memihak salah satu pihak yang bersengketa demi mencari kesepakatan dari keduanya, disini seorangmediator tidak memilliki kewenangan untuk memutuskan persengketaan, akan tetapi hanya sebatas memberikan bantuan dalam menyelesaikan permaslahan dari kedua belah pihak yang kemudian di kuasakan kepada seorang mediator. Ada beberapa definisi mediasi dari bebrapa versi yang berbeda, antara lain;

a. Christopher W. Moore mengatakan mediasi merupakan sebuah cara untuk mengintervensi pada sebuah sengketa atau bernegosiasi yang dilakukan oleh pihak ketiga, yang bisa di terima, tidak memihak salah satunya, dan bersikap netral. Seorang mediator disini tidak memiliki kewenangan dalam memutuskan putusan sengketa kedua belah pihak demi memperoleh kesepakatan atas perkara yang disengketakan oleh pihak-pihak yang bersengketa.

b. Menurut Folberg dan Taylor mediasi yaitu proses-proses mediasi pihak-pihak terkait sengketa dengan cara dibantu oleh satu orang atau lebih secara sistematis dalam upaya menyelesaikan permasalahan-permasalahan yang telah disengketakan untuk memperoleh sebuah pilihan dan mencapai suatu penyelesaian yang bisa digunakan untuk mengakomodasikan kebutuhan mereka.

c. UU nomer 30 Tahun 1999 terkait menyelesaikan sengketa merupakan sebuah lembaga yang diberi amanat untuk menyelesaikan sengketa yang memiliki perbedaan pendapat melalui beberapa prosedur yang telah disepakati bersama oleh para pihak terkait, salah satunya yaitu penyelesaian yang berada diluar pengadilan dengan cara berkonsultasi, melakukan negosiasi, konsiliasi, mediasi, atau dari penilaian ahli.

Adapun pengertian-pengertian diatas telah memberikan gambaran dan pengetahuan jika yang dimaksudkan dengan mediasi adalah sebuah usaha untuk menyelesaikan permasalahan/sengketa dari pihak-pihak terkait dengan hasil kesepakatan bersama melalui seorang mediator yang memiliki sifat tidak memihak, netral, dan tidak memberikan keputusan ataupun menyimpulkan untuk pihak-pihak yang terkait, akan tetapi memberikan fasilitas atau sebagai fasilitator bagi mereka demi terlaksananya komunikasi kedua belah pihak secara terbuka, jujur, dan bertukar pendapat untuk mencapai kata mufakat.

Beberapa arti mediasi yang sudah dikemukan sebelumnya bisa di sumpulkan terkait ciriciri dari proses bermediasi seperti;

a. Munculnya orang ketiga yang memiliki sikap tidak memihak dan netral, bisa memberikan artian bahwa seorang mediator tidak akan terlibat dalam permasalahan yang sedang disengketakan. Sikap yang netral dan tidak memihak bisa dikatakan sebagai bentuk tindakan yng tak bias dan tidak keberpihakan pada salah satu sengketa.

\footnotetext{
${ }^{24}$ S Sonhaji, "Analisis Yuridis Pemutusan Hubungan Kerja Akibat Kesalahan Berat Pekerja," Online Administrative Law \& Governance Journal $\quad 2, \quad$ no. $\quad 1 \quad$ (2019), https://brankaseverest.wordpress.com/artikel/pemutusan-hubungan-kerja/.
} 
b. Sebaiknya dalam pemilihan mediator adalah orang yang memiliki kepentingan bersengketa, akan tetapi juga bisa bagi mediator menawarkan dirinya untuk memberikan fasilitas memediasi, akan tetapi hal ini juga harus di setujui oleh pihk yang lain yakni arang yang bersangkutan dalam bersengketa.

c. Dalam menyelesaikan masalah harus di buat dan disepakati oleh kedua belah pihak yang memiliki permasalahan, dan juga harus bisa di terima oleh keduanya tanpa adanya rasa keter paksaan diantara mereka atau pihak manapun.

d. Tugas-tugas dari seorang mediator adalah harus bisa menjaga agar supaya dalam proses bernegosiasi tetap berjalan semestinya, membantu dengan memperjelas seluruh problema dan kepentingan-kepentingan dari seluruh pihak bertikai. Bisa dikatakan seorang mediator berperan dalam pengontrolan proses negosiasi, sedangkan peran dari pihak bertikai yakni mengontrol seluruh isi negosiasi.

Elemen-elemen mediasi, diantaranya adalah;

a. Menyelesaikan sengketa dengan suka rela tanpa paksaan.

b. Bantuan atau intervensi.

c. Ketidak berpihakan oleh orang ketiga.

d. Keputusan diambil oleh pihak-pihak terkait secara konsensus.

e. Pelaksanaanya dengan partisipasi yang aktif dari seluruh bagian yang terlibat sengketa kususnya mediator

Dalam beberapa pengertian mediasi yang sudah disampaikan, terlihat jelas jika dalam bermediasi melibatkan orang ketiga baik perseorangan ataupun bentuk lembaga independen yang memiliki sifat tidak memihak dan netral yang kemudian berfungsi sebagai seorang mediator. Sebagai seorang mediator yang telah ditunjuk oleh para pihak bersengketa ataupun oleh lembaga mediasi, maka seorang mediator memiliki kewajiban malakukan tugas dan fungsinya yang didasari atas kemauan dan kehendak dari para pihak. Pada waktu mediasi, proses penyelesaiannya lebih banyak timbul dari inisiatif dan keinginan pihak-pihak bersengketa, kemudian seorang mediator memiliki peran dalam membantu mereka-mereka yang bersengketa untuk mencapai tujuan sepakat. Upaya menolong pihak bersengketa, mediator harus memiliki sifat imparsial dan atau tidak memihak. ${ }^{25}$ Kedudukan seorang mediator yang semacam ini sangatlah penting, karena bisa menumbuhkan rasa percaya dan sangat memudahkan bagi seorang mediator untuk bisa melakukan kegiatan mediasi. Seorang mediator yang berpihak dan tidak netral, bisa menyulitkan kegiatan dalam bermediasi dan juga bisa membawa pada arah kegagalan sehingga tidak tercapai kesepakatan. ${ }^{26}$

Unsur-unsur mediasi terdiri dari tiga bagian yang saling berkaitan antara lain;
a. Ciri-ciri mediasi
b. Peran dari seorang mediator

\footnotetext{
${ }^{25}$ Lina Nur Annisa, "Implementasi Prinsip Neutrality dalam Proses Mediasi," Al Mabsut Jurnal Studi Islam dan Sosial 9, no. 1 (2015): 1-17, http://www.ejournal.iaingawi.ac.id/index.php/almabsut/article/view/20

26 Zabidin, "Mediasi Dalam Penyelesaian Sengketa Medis Sebagai Upaya Perlindungan Pasien," Jurnal.Unmas, 2016, 33-48.
}

Legality, ISSN: 2549-4600, Vol.27 No.2, September 2019-Februari 2020, hlm. 205-221 | 213 


\section{c. Kewenangan yang dimiliki oleh mediator}

Mediasi memiliki perbedaan dengan tehnik yang lainnya didalam penyelesaian sengketa, kususnya melalui jalur di luar pengadilan contohnya arbiterase. Pada waktu mediasi peran mediator adalah membantu pihak-pihak terkait untuk melakukan identifikasi masalah, kemudian mengembangkan pilhannya, dan selanjutnya mempertimbangkan juga beberapa alternatif-alternatif yang dimungkinkan bisa ditawarkan ke pihak-pihak terkait agar supaya tercapai sebuah kesepakatan. Selain itu juga mediator memiliki peran sebagai seorang yang menjalankan tugasnya untuk bisa memberikan saran-saran atau juga menentukan mediasi dengan mengusahakan penyelesaian sengketa, tidak hanya itu saja akan tetapi seorang mediator juga memiliki kewenangan dan berperan dalam menentukan keterkaitannya isi persengketaan, kemudian menjaga supaya proses dari mediasi bisa berjalan dengan baik ${ }^{27}$.

Selain efektif dalam menyelesaikan sengketa antar beberapa pihak, mediasi juga efektif menyelesaikan sengketa yang terkait dengan perlindungan konsumen, pembebasan tanah, perusakan lingkungan, dan juga perburuhan. Pihak yang bersengketa yang telah menggunakan jasa mediator tidak perlu lagi berbondong-bondong datang ke pengadilan atau juga sendirisendiri untuk menyelesaikan maslah yang telah di sengketakan, terkecuali masalah yang disengketakan yakni lewat jalur pengadilan hubungan industrial, pengadilan niaga, keberatan atas putusan Komisi Pengawas Persaingan Usaha, keberatan atas putusan badan penyelesaian sengketa konsumen, semua sengketa perdata yang diajukan ke Pengadilan tingkat pertama wajib lebih dahulu diupayakan melalui perdamaian dengan bantuan mediator. Mediasi non litigasi lebih banyak memberikan keuntungan dibandingkan mediasi litigasi. ${ }^{28}$

Ketentuan-ketentuan hukum di Indonesia, seperti mediasi dapat dibedakan menjadi 2 bagian yakni; mediasi litigasi atau mediasi di dalam pengadilan dan mediasi non litigasi atau bisa di sebut sebagai mediasi di luar pengadilan. Proses mediasi di pengadilan yakni para pihak akan saling bertatap muka, kemudian dari masing-masing pihak akan berupaya untuk mencoba mempertahankan seluruh argumenbeserta hak-hak dan keinginannya dihadapan pengadilan, yang kemudian hasil akhir dari proses penyelesaian sengketa ini adalah sebuah putusan yang bersifat win lose solution. ${ }^{29}$

Sering kali penyelesaian sengketamedik menggunakan proses litigasi, akan tetapi mediasi secara perlahan-lahan menjadi lebih dikenal oleh masyarakat dan lebih efektif efesien dalam menyelesaikan sengketa, kemudian kedua proses ini lama kelamaan menjadi saling bergantung satu dengan lainnya. Sengketa medik yang sedang di proses di pengadilan memiliki kewajiban

27 Anggraeni Endah Kusumaningrum, "Mediasi Dalam Penyelesaian Sengketa Medis Sebagai Upaya Perlindungan Pasien," Hukum Dan Dinamika Masyarakat 14, no. 1 (2016): 70-78.

28 Dedy Mulyana, "Kekuatan Hukum Hasil Mediasi Di Dalam Pengadilan Dan Di Luar Pengadilan

Menurut Hukum Positif," Jurnal Wawasan Yuridika 3, no. 2 (2019): 177-98, https://doi.org/10.25072/jwy.v3i2.224.

${ }^{29}$ Mulyana. 
untuk lebih mendahulukan proses mediasi sebelum adanya putusan pengadilan. ${ }^{30}$ Disini yang sangat mencolok adalah biaya sangat tinggi, waktu yang sangat lama, memiliki beban psikologis tinggi, dan kompleksitas dan formalitas proses litigasi.

Kerugian yang didapat saat menggunakan cara litigasi adalah jika di lihat dari sudut pandang seorang dokter dan atau rumah sakit maka akan memberikan dampak sangat buruk berupa nama baik menjadi tercemar, reputasi turun, kepercayaan masyarakat menurun, dan biaya asuransi profesi menjadi meningkat, hubungan dokter dengan pasien menjadi tidak baik 31 .

Proses mediasi yang dilakukan di luar pengadilan atau yang bisa disebut dengan non litigasi yang kemudian telah diatur didalam UU No.30/1999 tentang arbiterase dan alternatif dari proses penyelesaian sengketa. ${ }^{32}$ Selain itu juga di atur dalam peraturan perundangundangan dalam pasal 58 dan 60 No.49/2009 tentang kekuasaan kehakiman , pada BAB XII terkait upaya penyelesaian sengketa di luar pengadilan. Pada pasal 58 "sengketa medik bisa di selesaiakna di luar pengadilan negara melalui jalur arbiterase dan/ alternatif penyelesaian sengketa lainnya". Pasal 60 menentukan;

a. alternatif dalam penyelesaian sengketa adalah suatu lembaga yang bisa membantu dalam penyelesaian sengketa atau beda pendapat lewat suatu prosedur yang telah disepakati secara bersama-sama oleh pihak-pihak sengketa, yakni dengan cara konsultasi, mediasi, negosiasi, penilaian ahli dan konisliasi.

b. Sebagaimana telah dimaksud didalam ayat 1 yang hasilnya kemudian di tuangkan ke dalam kesepakatan tertulis.

c. Kesepakatan secara tertulis memiliki sifat final, hal ini sesuai dengan yang dimaksudkan didalam ayat 2 .

Alternatif penyelesaian sengketa atau yang disebut dengan Alternatife Dispute Resolution yang merupakan bagian dari suatu bentuk penyelesaian sengketa non litigasi. Selain itu penyelesain sengketa ini di pandang lebih efektif di bandingkan melalui jalur litigasi. ${ }^{33}$

Mediasi memiliki keistimewaan didalam proses penyelesaiannya antara lain; ${ }^{34}$

a. Sukarela dalam menerima keputusan mediasi yang sudah diserahkan kesepakatan para pihak

\footnotetext{
${ }^{30}$ Irfan and Hidayat, "Mediasi Sebagai Pilihan Penyelesaian Sengketa Medik Dalam Hukum Positif Indonesia."

${ }^{31}$ Irfan and Hidayat.

${ }^{32}$ Sari, "Mediasi Dalam Peraturan Mahkamah Agung No1 Tahun 2016."

${ }^{33}$ Slamet Suhartono, "Penggunaan Alternatief Dispute Resolution Dalam Penyelesaian Sengketa Antara Masyarakat Dengan Pemerintah," DiH: Jurnal Ilmu Hukum 7, no. 14 (2011): 72-84, https://doi.org/10.30996/dih.v7i14.264. Indonesia."

${ }^{34}$ Irfan and Hidayat, "Mediasi Sebagai Pilihan Penyelesaian Sengketa Medik Dalam Hukum Positif
} 
b. Sangat fleksibel, bahkan para pihak bisa membuat sendiri metode mediasinya dengan di bantu oleh mediator. ${ }^{35}$

c. Memiliki kepentingan dasar dari pihak yang bersengketa sehingga akan tetap terjaga kepentinganikepentingan yang dimmiliki mereka.

d. Selalu berpandangan ke depan, sebab menjaga kepentingan hubungan dari kedua belah pihak adalah hal yang sangat penting dan selalu berpandangan kedepan tanpa melihat masa lalu.

e. Prosedur non-formal yang digunakan memberikan para pihak berkepentingan bisa secara aktif untuk bisa mengontrol mediasi dan dalam pengambilan keputusan penyelesaian tidak selalu bergantung kepada pengacara ataupun advokat.

f. Sengketa yang telah diselesaikan lewat jalur mediasi adalah keputusan dari masingmasing pihak terkait. Seorang mediator tidak bisa memaksakan kehendak untuk memutuskan sudah tercapainya kesepakatan bersama begitu juga dengan pengacara yang tidak bisa menunda-nunda waktu atau memanfaatkan kondisi karena ketidak tahuan kliennya terkait hal-hal berita acara seperti di pengadilan.

Walaupun mediasi memiliki banyak sekali keuntungan, mediasi non litigasi masih memiliki kelemahan yakni adanya keterbatasan dukungan yang bersifat yuridis terhadap proses dan juga hasilnya, yang termasuk didalamnya adalah eksekusi perjanjian untuk menyelesaikan sengketa dengan hasil berupa perdamaian. Hasil dari satu proses dan keputusan tidak sematamata bisa dipaksakan sesuai dengan kehendak. Kelemahan lainnya adalah berasal dari Perma yang menurut urutan UU di Indonesia bahwa Perma tidak memiliki sifat wajib, dan mengikat sehingga hanya bisa digunakan sebagai pedoman. Sehingga perlu adanya pembentukan suatu undang-undang dalam memberikan kepastian hukum. ${ }^{36}$

Upaya-upaya dalam bermediasi seharusnya memang berbeda dengan upaya mediasi dipengadilan. Salah satu dari perbedaan mediasi yaitu upaya-upaya mediasi yang harus dilakukan secepat mungkin. Prinsip-prinsip dalam upaya bermediasi adalah hasil dari suatu putusan tidaklah mengutamakan atas pertimbangan dan alasan hukum, akan tetapi berdasarkan kesejajaran, kepatutan dan rasa keadilan, ${ }^{37}$

Tabel 1. Analisa mediasi litigasi dan non litigasi

\begin{tabular}{|l|l|l|l|l|l|}
\hline $\begin{array}{l}\text { Nomor } \\
\text { Putusan }\end{array}$ & $\begin{array}{l}\text { Mediasi } \\
\text { litigasi }\end{array}$ & $\begin{array}{l}\text { Mediasi } \\
\text { non } \\
\text { litigasi }\end{array}$ & Keuntungan & Kerugian & Analisa \\
\hline
\end{tabular}

${ }^{35}$ Asep Sukohar, Hendra Tarigan Sibero, and Maya Ganda Ratna, "Penyuluhan Mediasi Sengketa Medik Pada Dokter Yang Akan Diambil Sumpah Di Fakultas Kedokteran Unila,” JPM Ruwa JUrai 1, no. 1 (2015): 7174.

${ }^{36}$ Afandi, "Mediasi: Alternatif Penyelesaian Sengketa Medis."

${ }^{37}$ Jonathan Hendran A A W, "Rancangan Upaya Mediasi Sengketa Medis Di Rumah Sakit RK Charitas Palembang," Jurnal Manajemen Dan Administrasi Rumah Sakit Indonesia 3, no. 1 (2019): 1-8. 


\begin{tabular}{|c|c|c|c|c|c|}
\hline $\begin{array}{l}\text { Putusan } \\
\text { PN } \\
\text { No.38/ } \\
\text { Pdt.G/2 } \\
\text { 016/PN } \\
\text {.Bna }\end{array}$ & Gagal & - & $\begin{array}{l}\text { Kekuatan } \\
\text { hukum } \\
\text { mengikat, } \\
\text { kompensasi } \\
\text { sesuai } \\
\text { dengan UU, } \\
\text { kejelasan } \\
\text { hukum }\end{array}$ & $\begin{array}{l}\text { Dokter di } \\
\text { jabut SIP, } \\
\text { membayar } \\
\text { kompensasi, } \\
\text { di liput media } \\
\text { masa, nama } \\
\text { baik } \\
\text { tercoreng } \\
\text { dokter dan } \\
\text { RS }\end{array}$ & $\begin{array}{l}\text { Putusan pengadilan yang di } \\
\text { anggap masi tidak adil } \\
\text { karena menghilangkan } \\
\text { nyawa bisa di denda } \\
\text { sebesar besarnya adalah Rp } \\
1.000 .000 .000,-\end{array}$ \\
\hline $\begin{array}{l}\text { Putusan } \\
\text { Kasasi } \\
\text { no. } 155 \\
0 \\
\text { k/pdt/2 } \\
016\end{array}$ & - & $\begin{array}{l}\text { Berhasi } \\
1\end{array}$ & $\begin{array}{l}\text { Pasien } \\
\text { mendapatka } \\
\mathrm{n} \text { perawatan } \\
\text { perbaikan } \\
\text { lutut tanpa } \\
\text { mengeluark } \\
\text { an biaya }\end{array}$ & $\begin{array}{l}\text { Kompensasi } \\
\text { tidak sesuai } \\
\text { dengan } \\
\text { kecacatan } \\
50 \% \text { yang } \\
\text { mengakibatk } \\
\text { an kecacatan } \\
\text { permanen dan } \\
\text { tidak bisa } \\
\text { bekerja }\end{array}$ & $\begin{array}{l}\text { Pengadilan kurang adil } \\
\text { dalam memberikan putusan } \\
\text { meskipun pasien sejak awal } \\
\text { sudah menerima } \\
\text { kompensasi dari dokter } \\
\text { dengan di lakukan repair } \\
\text { genu di dokter yang } \\
\text { berbeda tanpa beban biaya, } \\
\text { dengan catatan biaya di } \\
\text { tanggung oleh dokter awal } \\
\text { yang melakukan kesalahan }\end{array}$ \\
\hline
\end{tabular}

\section{Dasar-Dasar Kekuatan Hukum Setelah Terputusnya Mediasi}

Keberhasilan dalam bermediasi oleh kedua belah pihak baik dalam pengadilan ataupun di luar pengadilan yang telah tercapai suatu kesepakatan berdamai, dengan bantuan dari mediator di buatkan kesepakatan perjanjian damai, seperti halnya tertuang dalam pasal 1/angka.8\&9/PERMA mediasi, atau bisa pada pasal 1851/KUHPerdata. Hasil mediasi berupa kesepakatan/perjanjian memiliki kekuatan hukum seperti pada perjanjian hukum biasa, hanya saja menjelaskan jika sudah terjadi hubungan hukum dar kedua belah pihak yang sudah membuatnya. Jika suatu hari ada pihak yang memiliki iktikad tidak baik pada waktu pelaksanaannya seperti yang telah di sepakati dalam perjanjian oleh mereka, maka pihak lainya yang merasa di rugikan bisa saja mengajukan ggatan wanprestasi ke pengadilan, sehingga bisa di katakan bahwa hasil dari sebuah perdamaian masih belum memiliki kekuatan hukum. Jika sudah terjadi kesepakatan bersama dan juga telah di tandatangani maka di wajibkan bagi kedua belah pihak untuk mendaftarkannya ke pengadilan negeri kurun waktu 30 haru setelah penandatanganan.

Dasar dari kesepakatan itu adalah pada pasal 6 ayat (7) UU No.30/1999 yang memiliki sifat final dan mengikat. Namun sifat tersebut harus didasari pada iktikad baik dari kedua belah pihak, sebaliknya sakah satu saja dari pihak bersengeketa memiliki iktikat tidak baik dan 
meskipun sudah di daftarkan di pengadilan maka tetap saja bisa di kataan tidak memiliki kekuatan eksekutor. Kepastian hukumnya kan menjadi efektif dan effesien jika para pihak mengukuhkan menjadi suatu akta damai, sehingga pada kesepakatan perdamaian bisa mempunyai kekuatan hukum.

Dalam kesepakatan perdamaian yang di sepakati dan dilaksanakan diluar pengadilan maka di haruskan terlebih dahulu mendaftarkan/mengajukan gugatan ke pengadilan Negeri yang memiliki kewenangan dalam meningkatkan status menjadi kesepakatan perdamaaian/perjanjian perdamaian yang kemudian menjadi akta perdamaian, seperi di atur dalam pasal 36 ayat (1) PERMA tentang mediasi. Pihak bersengketa yang melakukan mediasi melalui jalur pengadilan dan di bantu oleh seorang mediator maka cukup bagi mereka untuk mengajukan peningkatan pada majelis hakim yang telah memeriksa perkara menjadi sebuah akta perdamaian.

Ada 3 kekuatan hukum pada putusan perdamaian seperti halnya pada putusan biasa yaitu;

1. Kekuatan yang final dan mengkat.

2. Adanya kekuatan pembuktian secara sempurna

3. Bisa menjadi kekuatan eksekutor

Mengikat adalah setiap kata/butir yang sudah disepakati dan tertuang pada akta perdamaian maka bisa dilakukan dengan cara eksekutor oleh pengadilan. Final adalah ditingkatkannya menjadi status perdamaian kemudian jadi akta dama telah mengakhiri sekuruh upaya hukum laian bagi bagi pihak-pihak bersengketa, dan sesuai dengan pasal 1858 ayat 1 dan 2 KUHPerdata dan juga pasal $130 \mathrm{HIR}$, pasal $154 \mathrm{RBg}$ ayat 2 dan 3, dan pasal 1338 ayat 1 KUHPerdata.

Putusan PN No.38/Pdt.G/2016/PN.Bna, mediasi litigasi yang dilakukan telah gagal sehingga pengadilan memberikan keputusan dengan melihat bentuk upaya penyeembuhan dan bukan sebagai hasil penyembuh sehingga dasar hukum dan kekuatan hukum mediasi tidak berlaku, pengadilan kemudian memutuskan untuk mengabulkan sebagian tuntutan dan menolak sebagiannya, dengan memberikan ganti rugi kepada penderita sebesar Rp 200.000.000,- yang di tanggung renteng oleh beberapa pihak karena kelalaian yang telah dilakukan dan kurangnya pengawasan pihak rumah sakit kepada pegawai tenaga kesehatannya sehingga menyebabkan keterlambatan penanganan dan berujung meninggal dunianya korban.

Dalam Putusan MA No. 1550 K/Pdt/2016 mediasi yang dilakukan disini sesungguhnya sudah berhasil dengan kesepakatan dokter memberikan biaya kompensasi kepada pasien dengan melakukan repair pada genunya yang telah cacat akibat kesalahan pemasangan screw yang tidak kompeten, dan membebaskan seluruh biaya pengobatan sampai pasien mendapatkan perbaikan, namun karena ketidak puasan pasien akan hasil yang didapat dari pengobatan terakhir tidak memberikan hasil yang maksimal karena kesalahan awal pemasangan, sehingga pasien mengalami penderitaan kecacaan permanen sebesar 50\%, pasien melaporkan ke pengadilan namun di tolak, kemudian pasien mengajukan banding dan akhirnya putusannya juga di tolak, 
hal ini di karenakan dasar dari kekuatan hukum mediasi yang telah disepakati bersama antara dokter dengan pasien, sehingga pasien tidak bisa menuntut lebih kepada dokter.

\section{KESIMPULAN}

Sengketa medik pada umumnya di lakukan oleh seorang pasien yang memiliki rasa tidak puas kepada seorang dokter atau pihak rumah sakit, atau juga karena pasien merasa di rugikan oleh mereka, sehingga pasien mengajukan permasalah ini ke pengadilan karena kelalaian/kesalahan dari pihak rumah sakit dan atau dokter.

Dalam bersengketa kususnya kasus-kasus perdata pengadilan menyarankan untuk di lakukan upaya mediasi terlebih dahulu sebelum di lakukan putusan pengadilan. Hal ini guna untuk mencapai kesepakatan bersama tanpa merugikan salah satu pihak. Selain itu juga guna untuk mengurangi dampak buruk yang timbul di kemudian harinya seperti tercemarnya nama baik dokter dan rumah sakit sehingga banyak masyarakat yang menghakimi jika dokter dan atau rumah sakit tersebut telah melakukan wanprestasi, mengurangi beban psikologis yang terlalu tinggi, menekan biaya pengadilan, menekan biaya premi asuransi dokter, menekan waktu yang lama sehingga dengan bermediasi diharapkan bisa mempersingkat waktu dan tidak membuangbuang waktu.

Mediasi litigasi dan non litigasi sesungguhnya lebih efektif dan efesien pada mediasi non litigasi, karena memiliki keuntungan lebih banyak dibandingkan kerugiannya. Meskipun begitu setelah terjadi putusan bersama dan di tandangani maka seluruh pihak terkait harus mangajukan kesepakatan ke pengadilan guna unutk memberikan kekuatan hukum yang mengikat dan final, sehingga bisa di gunakan untuk melakukan eksekutor jika suatu saat ada salah satu pihak yang memiliki iktikatad tidak makakekuatan hukum bisa digunakan.

Dalam putusan PN No.38/Pdt.G/2016/PN.Bna meskipun mediasi litigasi dinyatakan gagal namun disi lain memberikan efek jera kepada dokter dan rumah sakit dengan harapan tidak terulang kembali, selain itu juga ijin praktek dokter juga dicabut sehingga odkter tidak bisa untuk praktek kembali, efek di adili di masyarakat dengan dampak dan image buruk di mata masyarakat bahwa dokter tersebut telah melakukan kesalahan yang mengakibatkan orang lain kehilangan nyawa.

Keberhasilan mediasi non litigasi pada Putusan MA No.1550 K/Pdt/2016 tidak berbanding lurus dengan harapan, meskipun dokter telah membebaskan seluruh biaya pengobatan dan operasi ulang, hal ini karena pasien telah mengalami kecacatan sebesar 50\%, yang seharusnya dari awal bisa di antisipasi jikalau dokter yang mengerjakan memiliki kompetensi yang mumpuni dan wawasan yang memadai.

\section{DAFTAR PUSTAKA}


Afandi, Dedi. "Mediasi: Alternatif Penyelesaian Sengketa Medis.” Majalah Kedokteran Indonesia 59, no. 5 (2009): 189-92.

Anggraeni Endah Kusumaningrum. "Mediasi Dalam Penyelesaian Sengketa Medis Sebagai Upaya Perlindungan Pasien.” Hukum Dan Dinamika Masyarakat 14, no. 1 (2016): 7078.

Anggraini, Rini, Suryono Yudha Patria, and Madarina Julia. "Ketepatan Waktu Pelayanan Skrining Hipotiroidism Kongenital Di Yogyakarta.” Sari Pediatri 18, no. 6 (2017): 436. https://doi.org/10.14238/sp18.6.2017.436-42.

Indar, Aminuddin syam, and Muh. Alwy Arifin. Etika Kesehatan Masyarakat. Yogyakarta: Pustaka Pelajar, 2020. https://www.docdroid.net/d7YQZw9/buku-etika-kesehatanmasyarakat-pdf\#page $=15$.

Indonesia, derektori putusan mahkamah agung republik. "Putusan Nomor $1550 \mathrm{~K} / \mathrm{Pdt} / 2016$." Bandung: direktori putusan mahkamah agung indonesia, 2016.

Irfan, Mohammad, and Syamsul Hidayat. "Mediasi Sebagai Pilihan Penyelesaian Sengketa Medik Dalam Hukum Positif Indonesia.” Jurnal IUS 6, no. 3 (2018).

Margerita Veani Prajati. "Penyelesaian Sengketa Medik Antara Pasien Dengan Dan/Atau Dokter Gigi Serta Rumah Sakit Demi Mewujudkan Hak Pasien.” Universitas Atmajaya. Atmajaya Yogyakarta, 2014.

Marzuki, Peter Mahmud. Penelitian Hukum. Jakarta: Kencana, 2005.

Mulyana, Dedy. "Kekuatan Hukum Hasil Mediasi Di Dalam Pengadilan Dan Di Luar Pengadilan Menurut Hukum Positif." Jurnal Wawasan Yuridika 3, no. 2 (2019): 177-98. https://doi.org/10.25072/jwy.v3i2.224.

Nurul Ummah, Fifik Wiryani, Moch. Nassir. "Perbuatan Melanggar Hukum Dalam Pelayanan Kesehatan (Analisis Putusan Pn No.38/Pdt.G/2016/Pn.Bna Dan Putusan Kasasi No.1550 k/Pdt/2016)." Magister Hukum Kesehatan UMM. Mhammadiyah Malang, 2020.

Ombeng, Gaby Pratty. "WANPRESTASI TERHADAP ISI PERJANJIAN DIVESTASI ANTARA PEMERINTAH INDONESIA DAN PT. NEWMONT NUSA TENGGARA." Lex Privatum 1, no. 5 (2015): 37-39. https://ejournal.unsrat.ac.id/index.php/lexprivatum/article/view/3080/2624.

Putusan, Direktori, Mahkamah Agung, Republik Indonesia, Demi Keadilan, Berdasarkan Ketuhanan, Yang Maha, Ulfa Wijaya Kesumah, et al. "Putusan Nomor 38/Pdt.G/2016/PN.Bna.” Banda Aceh: putusan mahkamah agung indonesia, 2016.

Sari, Septi Wulan. "Mediasi Dalam Peraturan Mahkamah Agung No1 Tahun 2016." Jurnal Ahkam 5, no. 1 (2017): 1-16.

Sonhaji, S. "Analisis Yuridis Pemutusan Hubungan Kerja Akibat Kesalahan Berat Pekerja." Online Administrative Law \& Governance Journal 2, no. 1 (2019). https://brankaseverest.wordpress.com/artikel/pemutusan-hubungan-kerja/.

Suhartono, Slamet. "Penggunaan Alternatief Dispute Resolution Dalam Penyelesaian 
Sengketa Antara Masyarakat Dengan Pemerintah.” DiH: Jurnal Ilmu Hukum 7, no. 14 (2011): 72-84. https://doi.org/10.30996/dih.v7i14.264.

Sukohar, Asep, Hendra Tarigan Sibero, and Maya Ganda Ratna. "Penyuluhan Mediasi Sengketa Medik Pada Dokter Yang Akan Diambil Sumpah Di Fakultas Kedokteran Unila." JPM Ruwa JUrai 1, no. 1 (2015): 71-74.

W, Jonathan Hendran A A. "Rancangan Upaya Mediasi Sengketa Medis Di Rumah Sakit RK Charitas Palembang." Jurnal Manajemen Dan Administrasi Rumah Sakit Indonesia 3, no. 1 (2019): $1-8$.

Zabidin. "Mediasi Dalam Penyelesaian Sengketa Medis Sebagai Upaya Perlindungan Pasien." Jurnal.Unmas, 2016, 33-48. 